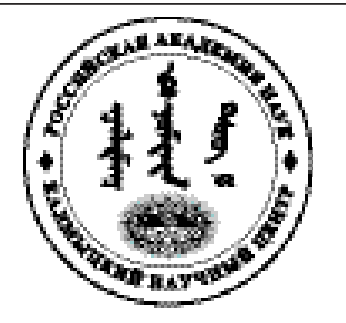

Published in the Russian Federation

Oriental Studies (Previous Name: Bulletin of the Kalmyk Institute

for Humanities of the Russian Academy of Sciences)

Has been issued as a journal since 2008

ISSN: 2619-0990; E-ISSN: 2619-1008

Vol. 13, Is. 5, pp. 1406-1414, 2020

DOI: $10.22162 / 2619-0990-2020-51-5-1406-1414$

Journal homepage: https://kigiran.elpub.ru

УДК 811.512 .141 '37

DOI: $10.22162 / 2619-0990-2020-51-5-1406-1414$

\title{
Лексико-семантический анализ лексемы балтырzан (с использованием материалов корпуса башкирского языка)
}

\author{
Анита Шаукатовна Иимухаметова
}

${ }^{1}$ Институт истории, языка и литературы Уфимского федерального исследовательского центра РАН (д. 71, пр. Октября, 450054 Уфа, Российская Федерация) младший научный сотрудник

iD 0000-0001-9603-654X. E-mail: ishmuhametova_anita@mail.ru

\author{
(C) КалмНЦ РАН, 2020 \\ (C) Ишмухаметова А. Ш., 2020
}

Аннотация. Выявление названий растительных средств в народных и художественных произведениях показывает тесное взаимодействие человека с миром, отношение людей к природе. Изучение фитонимов, а именно наименований лечебных растений, является важным шагом для понимания общего культурного наследия народа. В статье рассматривается лексема балтырван в башкирском языке. Материалом исследования послужили лингвистические словари, фольклорные и художественные тексты Машинного фонда башкирского языка, а также этимологические словари алтайских языков. Цель исследования - провести сравнительное изучение лексемы балтырған 'борщевик'. Результаты. Лексема балтырzан 'борщевик' является широкораспространенным фитонимом у башкир, об этом свидетельствует участие этой лексемы в номинации разных растений в башкирском языке, а также наличие параллелей в других тюркских и монгольских языках. Данный термин зафиксирован в академическом, толковом, диалектологическом, фразеологическом, мифологическом словарях башкирского языка. Сравнительный анализ показал, что baltyryan 'борщевик' во многих языках означает название растения из семейства зонтичных, лекарственное средство. В baltyryan baltiryana представлена первичная основа bal / baltïr / baldïr со значением 'зеленый, свежий, молодой'. Ключевые слова: башкирский язык, лексема, растительная лексика, борщевик, этимология, корпус башкирского языка

Благодарность. Исследование проведено в рамках государственной субсидии - проект «Создание корпуса диалектных текстов башкирского языка» (номер госрегистрации: АААА-А17-117040710023-4).

Для цитирования: Ишмухаметова А. Ш. Лексико-семантический анализ лексемы балтырган // Oriental Studies. 2020. T. 13. № 5. C. 1406-1414. DOI: 10.22162/2619-0990-2020-51-5-14061414 
UDC 811.512.141’37

DOI: $10.22162 / 2619-0990-2020-51-5-1406-1414$

\title{
Lexical and Semantic Analysis of the Lexeme baltyryan 'Hogweed': Based on the Corpus of the Bashkir Language
}

\author{
Anita Sh. Ishmukhametova ${ }^{1}$ \\ ${ }^{1}$ Institute of History, Language and Literature, Ufa Federal Research Centre of the RAS (71, Oktyabrya \\ Ave., Ufa 450054, Russian Federation) \\ Junior Research Associate
}

iD 0000-0001-9603-654X. E-mail: ishmuhametova_anita@mail.ru

\author{
(c) KalmSC RAS, 2020 \\ (C) Ishmukhametova A. Sh., 2020
}

\begin{abstract}
Identification of names of plant curatives and substances in folk and fiction texts shows close interactions between man and the world, attitudes of people towards nature. Research in phytonyms and medicinal plant names proper is most essential for the understanding of a nation's cultural heritage. The paper examines the lexeme балтырzан in Bashkir discourse. Materials. The analyzed materials include linguistic dictionaries, folklore and fiction texts of the Machine Fund of the Bashkir Language, and etymological dictionaries of Altaic languages. Goals. The study aims at a comparative investigation of the lexeme балтырган 'hogweed'. Results. The term proves a widespread phytonym in Bashkir discourse, which is attested by that it denotes a wide range of plant species in Bashkir and has parallels in other Turkic and Mongolic languages. The lexeme is included in academic, explanatory, dialectal, phrasal, and mythological dictionaries of the Bashkir language. The comparative analysis shows that baltyryan 'hogweed' usually denotes a plant of the order Apiales, a medicinal herb. Baltyryan baltiryana contains the initial bal / baltïr / baldï with the meaning 'green, young, fresh'.

Keywords: Bashkir language, lexeme, plant vocabulary, hogweed, etymology, Corpus of the Bashkir Language

Acknowledgements. The reported study was funded by state subsidy — project 'Creating a Corpus of Bashkir Dialectal Texts' (reg. no. AAAA-A17-117040710023-4).

For citation: Ishmukhametova A. Sh. Lexical and Semantic Analysis of the Lexeme baltyryan 'Hogweed': Based on the Corpus of the Bashkir Language. Oriental Studies. 2020. Vol. 13(5): 14061414. (In Russ.). DOI: 10.22162/2619-0990-2020-51-5-1406-1414
\end{abstract}

\section{है}

\section{Введение}

Растительный мир - неотьемлемая часть жизни любого народа. Средства растительного происхождения являются наиболее распространенными в народной медицине. Целительные свойства растений тысячелетиями использовались всеми народами мира. Обращаясь к природе, к ее дарам, люди лечили многие заболевания. Сегодня в мире насчитывается более 20000 лекарственных растений, которые обладают целительными свойствами. Благодаря широкому распространению, доступности и ценным свойствам, лекарственные растения используются с древнейших времен. Знания о свойствах лекарственных растений и их применении хранились в народной памяти, забывались, восстанавливались, пополнялись новыми сведениями и передавались из поколения в поколение. Следует отметить, что целый ряд названий растительных средств башкир встречается и у многих других народов. Одним из них является балтырван 'борщевик'. В конвенци- 
ональной медицине лекарственные препараты на основе борщевика не применяются, однако народная медицина их использует широко. Это растение обладает спазмолитическим, успокаивающим действием при нервном тике, истерии, невротических расстройствах, кожных заболеваниях, эпилептических припадках, имеет кровоостанавливающее и желчегонное воздействие на организм человека. Например, корни и плоды борщевика применяются, как правило, в качестве желчегонного средства при разнообразных гнойных и воспалительных процессах, желчнокаменной болезни, заболеваниях печени и воспалении почек. Чесотку, опухоли (наружно), онкологические заболевания, эпилепсию, понос в народе лечат отваром корня. Плоды используются при лечении депрессии, спазматических болях и истерии. Водные настои листьев и отвар корней борщевика применяются для корректирования функций желудочно-кишечного тракта и обмена веществ, а также в качестве седативного средства. Выделяется около 40 видов данного фитонима, часть из которых имеет обозначение в башкирском языке: каты балтырван 'борщевик жесткий', ярылган балтырган 'борщевик рассечёный', татлы балтырган 'борщевик сладкий', эре сәскәле балтырван 'борщевик крупноцветковый', ялбыр балтырzан 'борщевик пушистый', ябай балтырван 'борщевик обыкновенный', йөнтәс балтырдан 'борщевик мохнатый' и т. д. Цель исследования заключается в сравнительном изучении лексемы балтырған 'борщевик'.

Трактовка лексемы, диалектные варианты

Создание компьютерных словарей и размещение их в сети Интернет стало новым направлением современной лексикографии. Разработанный лабораторией лингвистики и информационных технологий отдела языкознания Института истории, языка и литературы Уфимского федерального исследовательского центра РАН Машинный фонд башкирского языка (далее - МФБЯ) является системой поиска материала для лингвистических исследований [Сиразитдинов 2019: 310]. Данная система включает в себя 12 специализированных баз данных. Из них 6 разделов содержат лексикографические данные.
Балтырған 'борщевик' является широко употребляемым словом в башкирском языке. Оно зафиксировано в большинстве словарей, которые вошли в МФБЯ.

В «Академическом словаре башкирского языка» даны следующие значения слова балтырван [боронғо төрки бал-тар 'йәш үлән'] <...> 1. бот. Көпшә һабакльы, киң киртлас япраклы, сатыр сәскәле күп йыллык Үлән (йәш савьлна яправьн, көпшәһен ашайзар) 'Многолетнее растение с трубчатым стеблем, широкими разрезанными листьями, цветки мелкие в крупных зонтиках (в пищу употребляют молодые листья, стебель)' ${ }^{\prime}$. 2. миф. Бианыуззар буйынса, һаклаусы, һаульк һәм көс биреусе үсемлек. Борщзевик (мифологизированное растение оберег, символ жизни, здоровья и силы). Балтырван ашын өс тапкыр ашаван йыл буйы ауырымлсс. Башкорт мифологияһынан 'Тот, кто трижды ел суп из борщевика, весь год не будет болеть' [Академический словарь 2011: 122].

В «Фразеологическом словаре башкирского языка» под редакцией 3. Г. Ураксина указано следующее устойчивое выражение, которое встречается в разговорной речи: балтырван тарау. Кунактан калган ашhыу менән икенсе кешеләрзе һьийлу 'Угощение других людей с оставшейся после гостей едой' [Фразеологический словарь 1996: 60].

В «Мифологическом словаре башкирского языка» Ф. Г. Хисамитдиновой даны следующие значения: балтырван - борщевник; мифологизированное растениеоберег, символ жизни, здоровья и силы. Балтырван ашын өс тапкыр ашаван йыл буйы ayырылмас. 'Тот, кто трижды ел суп из борщевника, весь год не будет болеть' [Хисамитдинова 2010: 53].

Народные названия фитонимов неоднозначны, и само растение может иметь несколько наименований. Названия лекарственных растений, как правило, отличаются богатством синонимических вариантов [Рубцова 2015: 6]. Значительный материал зафиксирован в «Диалектологическом словаре башкирского языка». Выделяют несколько диалектных названий этого растения: в среднеуральском говоре северо-западного диалекта - бикән көпшәс̧е;

\footnotetext{
1 Здесь и далее перевод автора данной ста-
} тьи. 
в сакмарском говоре южного диалекта, аргаяшском, миасском, салъютском говорах восточного диалекта и нижнебельском, караидельском, гайнинском, таныпском говорах северо-западного диалекта - көпшә. Башкиры данного диалекта называют неделю весеннего праздника с приготовлением пищи из борщевика көпшә жийыны 'праздник борщевика'. Молодую поросль борщевика в среднем и демском говорах южного диалекта называют бәбәк, а его завязь в среднем, ик-сакмарском говорах - бәпкә; Көпшәһен ашайлай, бәпкәһен кайнатып эсәләр 'Стебель едят, молодую поросль варят’; в гайнинском, таныпском, караидельском, нижнебельском говорах северо-западного диалекта - бикән, бутон борщевика в гайнинском говоре - пикан, караидельском говоре северо-западного диалекта - пикан / пикән, в нижнебельском, караидельском, гайнинском, таныпском говорах северо-западного диалекта и миасском, кизильском говорах восточного диалекта, сакмарском говоре южного диалекта - балдырzан [Диалектологический словарь 2002: 48, 69, 70, $153,263]$. В Куюргазинском районе Республики Башкортостан зафиксировано несколько фонетических вариантов: балmьрван / балдыркан / балтыркан.

\section{Этимология лексемы балтырzан}

Исторические преобразования общетюркской лексемы балтырван 'борщевик' рассматриваются в ряде этимологических исследований. В «Этимологическом словаре татарского языка» Р. Г. Ахметьянова к слову балтырган, диал. балдырган приводится значение 'борщевик; дягиль' [Ахметьянов 2015: 158]. В киргизско-русском словаре Н. К. Юдахина указывается, что балтырган / балдыркан / балтыркан 'купырь (растение)'; уу балтырzан 'болиголов (растение)'; аюу балтыркан 'борщевик (растение)' [Юдахин 1985: 106]. В «Этимологическом словаре чувашского языка» В. Г. Егорова: пултацран 'борщовник' [Егоров 1964: 165]. М. Р. Федотов в своем словаре указывает и фонетические варианты данной лексемы пултацран / пултран / полтран / путран / потран / пултацран / пулдьцран / пулдран 'борщовник' [Федотов 1996: 444]. В книге «Чувашские народные названия дикорастущих растений», посвященной сравнительно-историческому анализу лек- сико-семантической группы фитонимов, венгерский тюрколог Юдит Дмитриева подробно останавливается на чувашских диалектных формах: pultăran: a) poltran в первом слоге с $о$, характеризует верховой диалект чувашского языка; б) pultran-

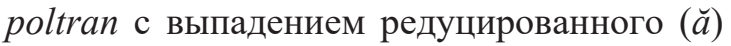
перед ударным слогом; в) putran/potran - с выпадением $l$ перед $t$, что также характеризует чувашские диалекты; г) pulătran - co вставкой $\breve{a}$ для облегчения произношения [Дмитриева 2001: 59].

В «Словаре тюркизмов в русском языке» ученый-лексикограф Е. Н. Шипова по материалам лексикографических источников дает следующие толкования: балдран 'растение Heracleum spondylium семейства зонтичных, борщевик обыкновенный, Heracleum sibirieum - борщевик сибирский’ [Шипова 1976: 58]. В «Опыте словаря тюркских наречий» В. В. Радлова имеются следующие сведения: балтырқан (кирг., каз.) - палдырқан 'борщевик' (Heracleum sibiricum); палдырқан (алт., тел., шор.) ‘борщевик, пичка'; различные виды: субаі палдырқан, тйктй палдырқан (алт.), ӓliк палдырқан (алт.), jyktȳ палдырқан 'сибирский борщевик’, anшаk палдырқан (шор.), mokai палдырқан (шор.); малтырқан (саг.) 'борщовник’ [Радлов 1893: 1503, 1172, 2041].

В «Этимологическом словаре тюркских языков» Э. В. Севортяна указывается: тур. балдыран / baldiran 'болиголов', чув. пултӑран / pulDăran 'борщевник', балдырван / baldiryan 'болиголов', аз. диал. 'бузина', кир. балтырzан / baltiryan 'купырь (трава)', ног. 'борщевник', тат. 'борщевник’, баш. 'борщевник', алт., алт. диал. балтырған / baltiryan 'дягиль', хак. палтырған / paltiryan 'дягиль', алт., тел., шор. палдырқан / paldiryan 'пучка', саг., сиб. тат. малтырған / maltiryan 'борщевник' [ЭСТЯ 1978: 55].

Финский ученый, лингвист-тюрколог М. Рясянен в своем «Этимологическом словаре тюркских языков» дает перечень данной лексемы: kaz. kkir. baltyryan 'Bärenkraut, heracleum', kaz. baldyryan, oir. tel. šor. paldyryan, sag. maltyryan, hak. paltyryan 'дягиль', sag. (hak.) maltyryan 'пучки', osm. blk. baldyryan 'assa foetida', AH. baldaran, osm. baldyran 'Spierstaude', čuv. pulDăran, potran 'Bärenklaue, mo. Lessing balčiryana, baldaryana 'heracleum dissektum' [Räsänen 
1969: 61]. Автор дает источник, в котором были зафиксированы некоторые слова: это труды арабского ученого Абу Хайян аль-Гарнати (1256-1344 гг.) и венгерского ученого Золтана Гомбоц (1877-1935) «Болгаро-турецкие слова на венгерском языке» (1912 г.).

Большинство приведенных названий обозначает растение Heracleum (Heracleum sibiricum, Heracleum sphondylium и др.) Это полевое растение, стебель которого находится в земле, из него готовят похлебку, суп. В диалектах турецкого (и киргизского) языка словом baldiran обозначается ядовитое растение (болиголов) из семейства зонтичных Conīum maculātum, произрастающее во влажных местах, имеются его разновидности büyük baldiran, küçük baldiran, su baldirani. Вероятно, в анализируемом названии смешались обозначения по крайней мере двух растений - одного съедобного, отменного лекарственного растения, на основе которого можно приготовить всевозможные полезные для организма средства, а другого - ядовитого. Таким образом, можно условно выделить балтырzан $^{l}$ (Heracleum 'борщевик') и балтырван ${ }^{2}$ (Conium 'болиголов').

Следует отметить, что общетюрское слово *baldiran имеет монгольские параллели: монг. balciryan-a, baldaryan-a (балчиргана 'борщевик сибирский', хар балчиргана 'семерица черная' [БАМРС 2001: 224]; калм. balčiryn (балчирhн 'борщевик' [КРС 1977: 80]), бур. balšaryana 'борщевик сибирский, чемерица' [Черемисов 1951: 90]). Монгольский афф. -үana обычно выступает в отыменных именах - обозначениях растений и животных; в тюркских языках ему соответствует афф. - $\gamma a n \sim-a n$. В тюрк. baltïryan монг. balčiryana выделяется основа baltïr, которую можно сопоставить с др.-уйг. baltï 'младшая родственница', ср. baldïz 'младшая сестра жены', халх. balčir 'малолетний', бур. balšar 'младенческий', як. balč yr, balక̌yr, baččyr $\leftarrow$ монг. (в составе balcyr oүo 'ребенок, подросший настолько, что начинает сидеть'). В «Древнетюркском словаре» балдыр / baldï - 'ранний': baldïr tarïy 'ранний посев'; балдыз / baldïz 'младшая сестра жены'; балтыр / baltï 'младший родственник' - эти термины, в свою очередь, были зафиксированы в словаре
Махмуда Кашгарского «Дӥвӓну луцӓт-иттурк» (Собрание тюркских наречий (языков), 1072-1074 гг.) [Древнетюркский словарь 1969: 80]. Возможно, производящей основой является балдыр / балтыр 'ранний; младший'.

Семантическая связь 'зеленый, свежий' - 'молодой, младший' прослеживается и в других языках: каз. balyyn šöp 'зеленая трава', baldyryan žas 'цветущая молодость', baldyryan žaқ 'пора ранней юности; юная пора' baldyryandik žas 'детский возраст, ранний возраст’ [Бектаев 1995: 88]; кирг. baldyryan žaš 'детский возраст', балтыргандай убагым (фольк.) 'время моего раннего детства' [Юдахин 1985: 106]; чув. пултӑр '1) шурин (младший брат жены); деверь (младший брат мужа); 2) свояченица (младшая сестра жены); золовка (младшая сестра мужа)' [ЧРС 1985: 309], пултӑр 'общее название младших братьев и сестер жены (для мужа), а также младших братьев и сестер мужа (для жены), т. е. младшие шурья и младшие свояченицы, младшие деверья и младшие золовки' [Федотов 1996: 443]; монг. балчир '1) малолетний, маленький, младенческий; балчир нас младенчество, младенческий возраст; балчир хүҮхэд дитя, младенец; 2) неопытный, зелёный, желторотый; балчир жаал молокосос, сосунок, мальчишка, мальчуган' [БАМРС 2001: 378].

В baltyryan baltiryana, видимо, представлена первичная основа bal co значением 'зеленый, свежий, молодой'.

Лексема балтырzан в произведениях корпуса башкирского языка

Материалом нашего исследования послужили тексты из корпусов прозаических и фольклорных текстов МФБЯ, в которых зафиксировано слово балтырған. В произведениях башкирского народного творчества (в поговорках, обычаях, сказках, эпосах, исторических кубаирах) исследуемая лексема встречается 12 раз: в форме балтырган - 2, балтырвандан - 2, балтыргандың - 1, балтырганы - 7. Ср.: Йылына бер балтырzан ашамаган кешенең эсе кортлар, имеш 'Якобы, у того, кто хотя бы один раз в год не ест борщевика, в желудке появятся черви' [КБЯ]. Май айында ете төрлө үлән ауыз итергә кәрәк. Балтырzандан өс тапкыр аш бешереп эсергә 'В мае надо пробовать семь разных трав. 
Трижды есть суп из борщевика' [КБЯ]. Таңдыса балтырвандың яправын, сывып кына килгән көпшәһен шыртылдата сәйнәn ашанып, тамак ялвап ала 'Тандыса питался листом и только что появившимся стеблем борщевика' [КБЯ]. Слово зафиксировано в эпосе «Иззел йорт» («Идель юрт»), в котором повествуется об исторических событиях XIV в. Ср.: Балтырzаны беләктәй, Балтырваны беләктәй; hарынаһы конандай... 'Борщевик - с локоть толщиной, борщевик - с локоть толщиной, саранка - высотой со стригунка...' [КБЯ]. Сравнительная конструкция Балтырганы беләктәй... 'Борщевик - с локоть толщиной...' встречается также в эпосах «Идукай и Мурадым», «Мэргэн и Маянхылу», «Урал батыр», в песне «Урал», где башкиры воспевают свой родной край, его красоту.

В прозаическом корпусе башкирского языка представлены восемь лексем с основой балтырган 'борщевик' в 85 словоупотреблениях: балтырван (72), балтырван $+z a$ (3), балтырган+дан (1), балтырган+дар (1), балтырган+ды (3), балтырган+ы (4), балтырган +ын (1), балтырган +ынан (2). Ср.: Батканга һалам да тотка, аска балтырган да бутка тигәндәй, студенттың күңелена өмөт кошо кундырыу өсөн, дллә кайзавы Карачуриндың йыйылмаган васкәре лә ярап куйзы. 'Как говорится, тонувшему и солома опора, голодному и борщевик каша, чтобы дать надежду душе студента, пригодилась еще не собранная армия Карачурина' [Гиззатуллин 1969].

Из текстов можно выявить этнографические сведения, связанные с борщевиком. Так, художественные тексты свидетельствуют о том, что он использовался в приготовлении балтырван ашы 'супа из борщевика'. Ср.: Ашта артык әллә ни ззә юк - кыркмава караһы булмаван ит тә һалынмаван, кузгалак йәки балтырван турап, ыуумас бетерела, һуган урынына - кылуыш йыууа, ә каймакты уйлаван юк инде ул, булһа - дсе катык та бик еткән, шулай за телеңде йоторлож аш 'В супе нет ничего такого - не добавлено мясо, с щавелем или борщевиком готовится затируха, вместо лука - лук-резанец, про сметану и не думаем, если есть то не помешал бы кислый катык, но все же суп получается так, что можно язык прогло- тить' [Бикбай 1968]; Балтырдан араһьıна он төшhә, уны азырак күкәй тугып, катык hальіп куйьртиаң,, йәшәп тә, эщләп тә була 'Если к борщевику добавить муку, сгустить со взбитым яйцом и катыком, можно и жить, и работать' [Гиззатуллин 1967]. Башкиры с давних времен знали полезные свойства растения балтырван 'борщевика', об этом свидетельствуют выявленные примеры из произведений башкирских писателей: Бер көндө күп итеп яс̧ы-ясы үлән япрактаpы, балтырzан йыйылn, һарына казып алыл кайтты каскы. - Был япрактарзы атайымм «башкорт кәбестоһе» тип, ашка һалдыра торвайны. Балтырван мендн һарынаны шул көйөнә аша, файзаль улар, - тине ул 'Однажды дезертир принес широченные листья трав, борщевика, саранку. Эти листья папа назвал «башкирской капустой» и просил класть в суп. Борщевик с саранкой ешь свежими, они полезные, - сказал он' [Поварисов 1996]. Известен факт, что посреди коренного населения края в прошлые века заболеваемость цингой встречалась очень редко. Об этом упоминается и в произведениях: Яз̧вы өзөктә йәшел балтырдан менән көмөш сабак ябай корһак туйымлькк кына түгел, а кыш озоно миктәп сыккан һаулыгын нывыткыс танһык аш - зәнцгәләндн витамин булган 'Весной зеленый борщевик с серебряной сорогой не только наполняет желудок, но и после долгого зимнего обострения является полезной едой - витамином от цинги' [Султанов 1996].

Ни в одном из рассмотренных произведений балтырган 'борщевик' как ядовитое растение не встречается. При помощи диких съедобных трав люди спасались во время войны и послевоенные голодные годы, ими восполняли недостаток витаминов в организме. Большинство авторов в своих произведениях описывают, как башкиры готовили балтырган ашы 'суп из борщевика'. С древних времен из уст в уста передавалось поверье, что весной надо поесть этот суп не менее трех раз и его целебных свойств хватит на год. Эта традиция сохранилась и по сей день. В деревнях представители старшего поколения в период с 3 по 17 июня собирают свежие молодые листья балтырван 'борщевика', добавляют кесерткән 'крапиву', ыуммас 'затируху' и готовят суп, угощают детей. 


\section{Выводы}

В башкирском языке существует разработанная система номинаций разновидностей этого растения: каты балтырган 'борщевик жесткий', ярылван балтырган 'борщевик рассечённый', татль балтырган 'борщевик сладкий', эре сәскәле балтырган 'борщевик крупноцветковый’, ялбыр балтырган 'борщевик пушистый', ябай балтырган 'борщевик обыкновенный', йөнтәс балтырган 'борщевик мохнатый' и т. д. Данный термин зафиксирован в академическом, толковом, диалектологическом, фразеологическом, мифологическом словарях башкирского языка. Параллели к слову балтырған имеются в большинстве алтайских языков: тюркских - baltyryan 'борщевник' (чаг.); baldyran ‘болиголов’ (тур.); baldyryan ‘борщевник' (аз.); baldyryan 'борщевник' (кбалк.), baltiryan 'борщевник’ (тат.), baltyryan 'борщевник' (ног.), baldyryan 'pacтение со сладким сочным стеблем / борщевник' (каз.); baldyryan, 'купырь' (кирг.), baltyryan 'дягиль' (алт.); paltyryan 'дягиль'

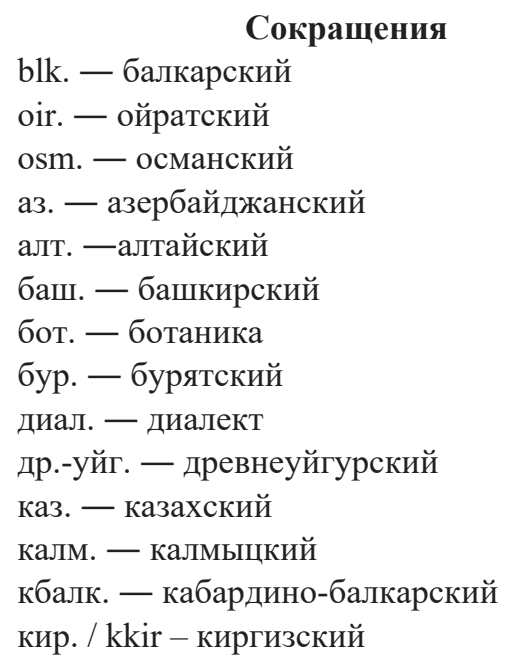

\section{Источники}

КБЯ - Корпус башкирского языка. Проза [электронный ресурс] // URL: http://212.193.132.98/bashkorp/bashkorp (дата обращения: 16.11.2020).

\section{Литература}

Академический словарь 2011 - Академический словарь башкирского языка. В 10 т. Т. 2. Уфа: Китап, 2011. 568 с. (хак.); pultăran 'борщевник’ (чув.) и монгольских — balciryan-a (монг.), baldaryan-a 'борщевик' (калм.), balšaryana 'борщевик сибирский, чемерица' (бур.).

Сравнительный анализ показал, что baltyryan 'борщевик' во многих языках обозначает растение из семейства зонтичных, которое является лекарственным средством. Следует также отметить, что в baltyryan baltiryana представлена первичная основа bal / baltïr / baldïr со значением 'зеленый, свежий, молодой'.

Обнаружение лексемы балтырzан в трудах тюркских ученых, произведениях башкирского народа с XIV в. свидетельствует о его значительной исторической ценности.

Выявление названий растительных средств в народных и художественных произведениях показывает тесное взаимодействие человека с миром, отношение людей к природе. Изучение фитонимов, а именно наименований лечебных растений, является важным шагом в понимании общего культурного наследия народа.

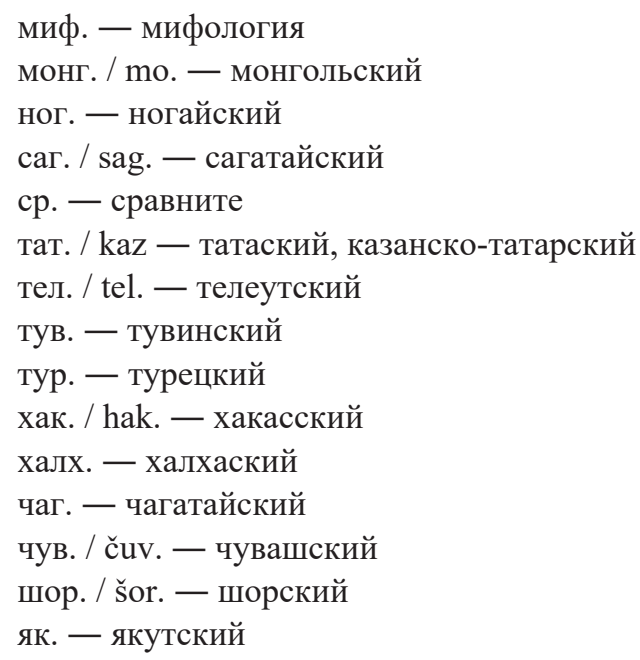

\section{Sources}

Corpus of the Bashkir Language. Prose Fiction. Available at: http://212.193.132.98/bashkorp/ bashkorp (accessed: November 16, 2020). (In Bash.)

Ахметьянов 2015 - Ахметьянов Р. Г. Этимологический словарь татарского языка. В 2 т. Т. 1. А-Л. Казань: Магариф-Вакыт, 2015. $540 \mathrm{c}$. 
БАМРС 2001 - Большой академический монгольско-русский словарь в 4-х томах / под общ. ред. А Лувсандэндэва и Ц. Цэдэндамбы. Т. 1: А-Г. М.: ACADEMIA, 2001. 498 c.

Бектаев 1995 - Бектаев K. Большой казахско-русский русско-казахский словарь. Алматы: изд-во, 1995. 703 с.

Бикбай 2004 - Бикбай Б. Живые родники: Повесть. Уфа: Китап, 2004. 328 с.

Бускунбаева 2017 - Бускунбаева Л. А., Сиразитдинов 3. А., Иимухаметова А. Ш. Состав и структура корпуса публицистики башкирского языка // Электронная письменность народов Российской Федерации: опыт, проблемы и перспективы. Сыктывкар, 16-17 марта 2017 г. С. 39-43.

Гиззатуллин 1969 - Гиззатуллин И. Второй гром: Повесть. Уфа: Китап, 1969. 283 с.

Диалектологический словарь 2002 - Диалектологический словарь башкирского языка / отв. ред. М. И. Дильмухаметов. Уфа: Китап, 2002. $432 \mathrm{c}$.

Дмитриева 2011 - Дмитриева Ю. Чувашские народные названия дикорастущих растений (Studies in Linguistics of the Volga-region) / ed. by K. Agyagási. Vol. I. Debrecen, 2001. $211 \mathrm{c}$.

Древнетюркский словарь 1969 - Древнетюркский словарь / ред. Наделяев В. М., Насилов Д. М., Тенишев Э. Р., Щербак А. М. Л.: Наука, ЛО АН СССР, 1969. 677 с.

Егоров 1964 - Егоров В. Г. Этимологический словарь чувашского языка. Чебоксары: Чувашск. кн. изд-во, 1964. 355 с.

КРС 1977 - Калмыцко-русский словарь. М.: Русский язык, 1977. 764 с.

Радлов 1899 - Радлов В. В. Опыт словаря тюркских наречий. Т. 2. Ч. 1. СПб.: Тип. Российской Императорской Академии Наук, 1899. 1052 c.

Рубцова 2015 - Рубиова О. Г. Названия лекарственных растений в разноструктурных языках: на материале русского, марийского, немецкого и латинского языков: дис. ... канд. филол. наук. Йошкар-Ола, 2015. 217 с. Сиразитдинов 2016 - Сиразитдинов 3. A., Бускунбаева Л. А., Шамсутдинова Г. Г., Иимухаметова А. Ш., Каримова Р. Н. О корпу-

\section{References}

Akhmetyanov R. G. Etymological Dictionary of the Tatar Language. In 2 vols. Vol. 1: A-Л. Kazan: Magarif-Vakyt, 2015. 540 p. (In Tat.) се башкирского фольклора // Гуманитарная наука Юга России: международное и региональное взаимодействие. Мат-лы II Междунар. науч. конф., посвящ. 75-летию Калмыцкого института гуманитарных исследований РАН (г. Элиста, 14-15 сент. 2016 г.). Элиста: КИГИ РАН, 2016. С. 272-274.

Сиразитдинов 2018 - Сиразитдинов 3. А., Бускунбаева Л. А., Иимухаметова А. Ш., Шамсутдинова Г. Г. О лингвистических корпусах башкирского языка // XXI ғасырдың ғылыми-ағартушылық парадигмалары: рухани құндылықтар аясындағы тіл және мәдениет. Алматы, 2018. С. 276-280.

Сиразитдинов 2019 - Сиразитдинов 3. А. Электронные ресурсы башкирской лексикографии // Башкирский язык и литература в условиях глобализации и полиэтнической среды: опыт и перспективы: Мат-лы Междунар. науч.-практ. конф. Уфа: ИИЯЛ УФИЦ РАН, 2019. C. 309-319.

Федотов 1996 - Федотов М. Р. Этимологический словарь чувашского языка. Т. 2. Чебоксары: Чувашский государственный институт гуманитарных наук, 1996. 509 с.

Фразеологический словарь 1996 - Фразеологический словарь башкирского языка / 3. Г. Ураксин. Уфа : Китап, 1996. 287 с.

Хисамитдинова 2010 - Хисамитдинова Ф. Г. Мифологический словарь башкирского языка. М.: Наука, 2010. 452 с.

Черемисов 1951 - Черемисов К. М. Бурят-монгольско-русский словарь. М.: Гос. изд-во иностр. и нац. словарей, 1951. 852 с.

ЧРС 1985 - Чувашско-русский словарь / под ред. М. И. Скворцова. М.: Рус. яз., 1985. $712 \mathrm{c}$.

Шипова 1976 - Шипова Е. Н. Словарь тюркизмов в русском языке. Алма-Ата, "Наука" Каз ССР, 1976. 444 с.

ЭСТЯ 1978 - Этимологический словарь тюркских языков (Общетюркские и межтюркские основы на буквы «Б»). М.: Наука, 1978. 349 c.

Юдахин 1985 - Юдахин Н. К. Киргизско-русский словарь. М., 1985. 973 с.

Räsänen 1969 — Räsänen M. Versuch eines etymologischen wörterbuchs der türksprachen. Helsinki. 1969. 533 s.

Bektaev K. Unabridged Kazakh-Russian and Russian-Kazakh Dictionary. Almaty, 1995. 703 p. (In Kaz. and Russ.)

Bikbay B. The Living Springs. Novel. Ufa: Kitap, 2004. 328 p. (In Bash.) 
Buskunbaeva L. A., Sirazitdinov Z. A., Ishmukhametova A. Sh. Corpus of Bashkir Journalistic Texts: composition and structure. In: Fedina M. S. (ed.) Digital Solutions for Russia's Languages. Experiences, Problems and Prospects. Conference Proceedings (Syktyvkar; March 16-17, 2017). Syktyvkar: Komi Academy of National Economy and Management, Pp. 39-43. (In Russ.)

Cheremisov K. M. Buryat Mongolian-Russian Dictionary. Moscow: State Publ. House of Foreign and National Dictionaries, 1951. 852 p. (In Bur. and Russ.)

Dilmukhametov M. I. (ed.) Dialectal Dictionary of the Bashkir Language. Ufa: Kitap, 2002. 432 p. (In Bash.)

Dmitrieva Yu. Chuvash Names of Wild Plants. Ser.: Studies in Linguistics of the Volga Region. K. Agyagási (ed.). Vol. I. Debrecen, 2001. 211 p. (In Chuv. And Russ.)

Egorov V. G. Etymological Dictionary of the Chuvash Language. Cheboksary: Chuvash Book Publ., 1964. 355 p. (In Chuv. and Russ.)

Fedotov M. R. Etymological Dictionary of the Chuvash Language. Vol. 2. Cheboksary: Chuvash State Institute for the Humanities, 1996. 509 p. (In Chuv. and Russ.)

Gizzatullin I. The Second Thunder. Novel. Ufa: Kitap, 1969. 283 p. (In Bash.)

Khisamitdinova F. G. (ed.) Academic Dictionary of the Bashkir Language. In 10 vols. Vol. 2. Ufa: Kitap, 2011. 568 p. (In Bash.)

Khisamitdinova F. G. Mythological Dictionary of the Bashkir Language. Moscow: Nauka, 2010. 452 p. (In Bash.)

Muniev B. D. (ed.) Kalmyk-Russian Dictionary. Moscow: Russkiy Yazyk, 1977. 764 p. (In Kalm. and Russ.)

Nadelyaev V. M., Nasilov D. M., Tenishev E. R., Shcherbak A. M. (eds.) Dictionary of Old Turkic. Leningrad: Nauka, 1969. 677 p. (In Turk. and Russ.)

Pyurbeev G. Ts., Luvsandendev A., Tsedendamba Ts. (eds.) Unabridged Academic Mongolian-Russian Dictionary. In 4 vols. Vol. 1: A- . Moscow: Academia, 2001. 498 p. (In Mong. and Russ.)
Radlov V. V. A Dictionary of Turkic Dialects. Vol. 2. Part 1. St. Petersburg: Imperial Academy of Sciences, 1899. 1052 p. (In Turk. and Russ.)

Räsänen M. Versuch eines etymologischen wörterbuchs der türksprachen (An Etymological Dictionary of the Turkic Languages). Helsinki. 1969. 533 p. (In Turk. and Germ.)

Rubtsova O. G. Medicinal Plant Names in Structurally Different Languages: A Case Study of Russian, Mari, German, and Latin. Cand. Sc. (philology) thesis. Yoshkar-Ola, 2015. 217 p. (In Russ.)

Sevortyan E. V. Etymological Dictionary of the Turkic Languages: Common and Intra-Turkic Stems Beginning with the Letter 'B'. Moscow: Nauka, 1978. 349 p. (In Turk. and Russ.)

Shipova E. N. Dictionary of Turkisms in Russian. Alma-Ata: Nauka, 1976. 444 p. (In Russ.)

Sirazitdinov Z. A. Online resources of Bashkir lexicography. In: Bashkir Language and Literature amidst Globalization and Polyethnic Environment. Experiences and Prospects. Conference Proceedings. Ufa: Institute of History, Language and Literature (Ufa Fed. Res. Centre of RAS), 2019. Pp. 309-319. (In Russ.)

Sirazitdinov Z. A., Buskunbaeva L. A., Ishmukhametova A. Sh., Shamsutdinova G. G. About linguistic corpuses of the Bashkir language. In: Scientific and Educational Paradigms of the $21^{\text {st }}$ Century. Language and Culture in the Context of Spiritual Values. Almaty, 2018. Pp. 276280. (In Russ.)

Sirazitdinov Z. A., Buskunbaeva L. A., Shamsutdinova G. G., Ishmukhametova A. Sh., Karimova R. N. About the Corpus of Bashkir Folklore. In: Humanities of Southern Russia. International and Regional Cooperation. Conference Proceedings. Elista, 2016. Pp. 272-274. (In Russ.)

Skvortsov M. I. (ed.) Chuvash-Russian Dictionary. Moscow: Russkiy Yazyk, 1985. 712 p. (In Chuv. and Russ.)

Uraksin Z. G. Bashkir Phraseological Dictionary. Ufa : Kitap, 1996. 287 p. (In Bash.)

Yudakhin N. K. Kyrgyz-Russian Dictionary. Moscow, 1985. 973 p. (In Kyrg. and Russ.) 